\title{
Archival Document Packets: A Teaching Module in Advocacy Training Using the Papers of Governor Dick Thornburgh
}

\author{
Richard J. Cox, Janet Ceja Alcalá, and Leanne Bowler
}

\begin{abstract}
A bst ract
Archivists have been involved for a long time in working with educators at all levels to use archival sources. Having graduate archival studies students work on documentary teaching packets is also a way for students preparing for archival careers to learn how to become advocates for archives. At the University of Pittsburgh-in a course called Archival Access, Ethics, and Advocacy - students drew on the extensive Governor Dick Thornburgh Papers to construct document teaching packets. This article provides background in the use of such packets in archival advocacy and public education, discusses the successes and challenges of such an assignment, and offers insights for graduate archival education. Whether or not the final products were useful is not important, as the students learned about how to be advocates and the nature of large archival collections.
\end{abstract}

A

rchivists became interested in working with $\mathrm{K}-12$ and other educators some thirty years ago, producing an array of conceptual, case, and research studies. Much of this work is built around educators' pedagogical theories and aims-such as critical thinking and information literacy-and more recently reflects common core educational standards. While archivists debate what their role should be in such educational goals, they generally accept that understanding such pedagogies is useful for building bridges between teachers and themselves. Many academic archivists also seize opportunities to teach undergraduates about the nature of research in their repositories, lifting the veil from their professional practices. The growth of archival resources and the increasing presence of archivists on the Web also raise the potential for new ways of engaging students to build greater knowledge (C) Richard J. Cox, Janet Ceja Alcalá, and Leanne Bowler 
about archives. If archivists seek partnerships with teachers to learn how to present their sources for use by both teachers and students, teachers ought to be trying to secure a partnership with archivists to learn about the nuances of archival sources. A high school student critically evaluating a documentary source will be better served by a teacher with rich contextual information about what such a source represents.

Recent initiatives to develop a common set of educational standards for English language arts and mathematics at the K-12 levels across the United States may compel teachers to focus even more closely on the reading and interpretation of primary source materials. The Common Core State Standards, currently adopted by forty-five states, are meant to provide a "consistent, clear understanding of what students are expected to learn." Among those expectations are benchmarks for reading and interpreting history, using primary and secondary sources (the Common Core Standards refer to this as "literacy in history"). According to the Common Core Standards, students in grades nine to twelve should be able to

- "Cite specific textual evidence to support analysis of primary and secondary sources;

- Determine the central ideas or information of a primary or secondary source;

- $\quad$ Provide an accurate summary that makes the relationships among the key details and ideas; and

- Analyze in detail a series of events described in a text; determine whether earlier events caused later ones or simply preceded them." ${ }^{2}$

With literacy for history quite literally woven into the fabric of a nationwide movement to standardize education, it seems that now is the opportune moment to think about the kind of training that archival students receive in support of education and outreach. Reading through descriptions about the use of archival sources in teaching from middle school to the university, it became apparent that having archives students prepare teaching packets would be an excellent way for them to experience how to become advocates for archives. This essay describes such a learning experience in the Archival Access, Advocacy, and Ethics class at the University of Pittsburgh, where students prepared a teaching packet using the Governor Dick Thornburgh Papers. We first provide background in archival teaching packets and their role in both archival advocacy and public education. We then describe the purpose, objectives, and methods used in the assignment, concluding with a discussion of some of the obstacles the students faced in the assignment and offering some insight for future teaching in this area. This is not a research study about

1 Common Core State Standards Initiative (2012), http:/ / www.corestandards.org/, accessed 5 July 2012.

2 Common Core State Standards Initiative. 


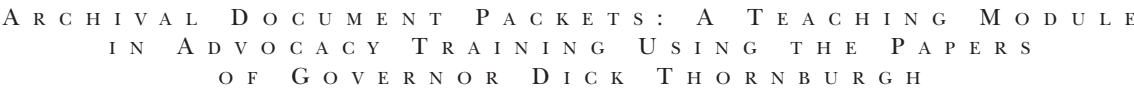

the students, but, rather, a descriptive analysis of the value of incorporating such an exercise into a graduate course.

\section{Archivists Working with Educators}

Students interacting with archival and other historical materials is certainly nothing new. More than thirty years ago, History Day made its debut, intending to strengthen the teaching of history in the public school system. This is probably the best known of the efforts to engage school children in working with archival sources, but it was not the first. The American Historical Association's efforts to work with schools occurred long before History Day. Charles A. Beard in his A Charter for the Social Sciences in the Schools, published in 1932, argues that imparting information and knowledge in classrooms "can be promoted by discipline in the methods of attaining access to information-the use of encyclopedias, authorities, documents, sources, statistical collections," what he terms "authoritative materials." Gary Nash claims that such efforts date back to the 1890s when the National Education Association reviewed history teaching, concluding that such teaching needed to move beyond lectures based on often dull textbooks. ${ }^{4}$

The use of oral history for classroom projects, part of a then-fledgling movement by history professors to get their students to use archival materials and to engage in historical research, laid the groundwork for History Day. ${ }^{5}$ Teaching oral history to undergraduates began in the 1950s following the creation of official oral history research offices as early as $1948 .{ }^{6}$ By the $1960 \mathrm{~s}$

3 American Historical Association, Charles Austin Beard, and August C. Krey, A Charter for the Social Sciences in the Schools: Report of the Commission on the Social Studies, part 1 (New York: Scribners, 1932, reprinted 2008), 99.

4 Gary B. Nash, "Creating History Standards in United States and World History," OAH Magazine of History 9 (1995): 3.

5 See, for example, Barry A. Lanman, "The Use of Oral History in the Classroom: A Comparative Analysis of the 1974 and 1987 Oral History Association Surveys," The Oral History Review 17 (Spring 1989): 215-26. Beatrice Spade, in this period, reflects, "Members of the history faculties are no longer just teaching undergraduates about history; instead they are sending their students out to do historical research. Many of the research projects that have been planned for undergraduates involve oral history techniques and have focused on family or local history. Such projects have been largely developed and applied in the field of American history." Beatrice Spade, "Americans in Vietnam: An Oral History Project," The History Teacher 8 (February 1975): 183. Oral history has remained a popular way of introducing students to and engaging them in historical research, as one commentator observes, "The goals stated by faculty teaching oral history can be summarized as two broad tasks: to explore oral history as a research method and as a form of historical evidence; and to give students practical knowledge or experience in the ways oral evidence and interviewing can be used in a public history career." Tracy E. K'Meyer "'It's Not Just Common Sense': A Blueprint for Teaching Oral History," The Oral History Review 25 (Autumn 1998): 37. See also Sherna Berger Gluck, Donald A. Ritchie, and Bret Eynon, "Reflections on Oral History in the New Millennium: Roundtable Comments," The Oral History Review 26 (Summer/Autumn 1999): 1-27.

6 Donald A. Ritchie, Doing Oral History, Twayne's Oral History Series, no. 15 (New York: Twayne Publishers, 1995), 22. 
came noteworthy efforts to use oral history in the $\mathrm{K}-12$ environment, most importantly the well-known and popular Foxfire program in Georgia, leading to the publication of many books touting oral history as a teaching tool. ${ }^{7}$ Contests for papers, projects, and performances began to be held, showcasing original historical research conducted by K-12 students. And, as one account of the evolution of History Day suggests, greater expectations were envisioned: "Nor should it be assumed that opening a family trunk, interviewing a distant aunt, or exploring one's own background is merely a narrow exercise in selfknowledge, a delimiting experience, psychologically satisfying to be sure, but not one consistent with what one usually associates with the value of historical study - an increased understanding of the human experience in all its varied cultural, political, and economic aspects." ${ }^{\circ}$ History Day pushed students to investigate and learn about local archival and historical materials, using materials close at hand and easier for both teachers and students to access. ${ }^{9}$ It was part of a growing sensitivity to the possibilities of connecting students to the past and their local communities. And, of course, many archivists were involved.

It is no accident that History Day emerged when it did, with slowing employment prospects for history doctorates. Today, those writing about historians and archivists being involved with K-12 classrooms place it in the same, even worse, employment circumstances. Historian Brad Austin revealingly writes, "It's statistically highly unlikely that successful PhD candidates (including many from 'elite' programs) will get jobs at elite doctoral programs. Instead, most who do get jobs will get them at schools where they are much more likely to be responsible for training future K-12 educators, than for preparing 'academic' historians. ..." Austin adds, "Since most graduate students eventually become teachers of some sort (museum educators, professors, K-12 teachers, public historians), having a structured conversation about what constitutes good history teaching makes a lot of sense." 10 Who can disagree with this? And what is the archival equivalent of such a sentiment?

7 Such books include James Hoopes, Oral History: An Introduction for Students (Chapel Hill: University of North Carolina Press, 1979); John Neunshwander, Oral History as a Teaching Approach (Washington, D.C.: National Education Association, 1976); Rebecca Oxford, Language Learning Strategies: Conversation Skills through Oral Histories (Boston: Heinle, 1989); and the guide by the Oral History Association titled Oral History in the Secondary School Classroom by Barry A. Lanman and George L. Mehaffy (1998). See Cliff Kuhn and Marjorie L. McLellan, "From the Editor: Oral History," OAH Magazine of History 11 (1997): 3-5.

8 David Wallace Adams and Marvin Pasch, "The Past as Experience: A Qualitative Assessment of National History Day," The History Teacher 20 (February 1987): 187.

9 Mary E. Anthrop, "History Day Advisor Tells How Students Got Started," Magazine of History 1 (Winter/ Spring 1986): 31.

${ }^{10}$ Brad Austin, "K-12 Teaching: Why Should We Care?," Perspectives on History 46 (May 2008), American Historical Association, http://www.historians.org/perspectives/issues/2008/0805/0805tea1.cfm, accessed 9 July 2010. 


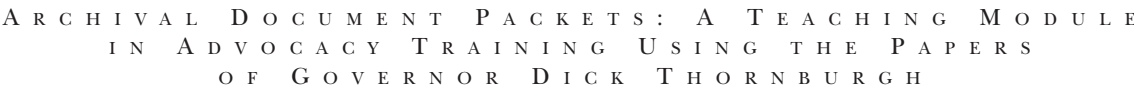

Archivists and the Use of Primary Sources in Teaching

Most of the writing about the use of archives and other historical materials in the classroom focuses on grades $\mathrm{K}-12$, where archivists have been seeking to have their primary sources used for nearly half a century. ${ }^{11}$ The breakthrough primer about the use of archival materials in the classroom is Kathleen Roe's 1981 publication, which offers both a rationale for this and examples of the use of particular kinds of documents in the classroom. ${ }^{12}$ However, the amount of literature written by archivists concerning the use of archival sources is modest compared to what educators (nonarchivists) themselves have written as a result of shifts in K-12 pedagogy. This may be because, according to Julia Hendry, "Ascendant pedagogical theories about the importance of 'inquiry-based learning,' combined with the content of many standardized tests, makes the use of primary materials de rigueur in many elementary and secondary school classrooms." 13 The presidential libraries, for example, have drawn on educational research to model programs utilizing archival sources to assist students in becoming independent learners and to focus on "Character Education," a national movement interested in ethical aspects of K-12 education. ${ }^{14}$ Given how little most K-12 educators know about archival sources, archivists themselves can convey to the teaching community the requisite knowledge to select, interpret, and build educational packets of archival sources.

Archivists have noticed that "archival topics continue to make it onto the evening news" and that "many archival matters are significant public policy issues," 15 reminding us of the political aspects of archival work. Elena Danielson's balanced assessment of the implications of WikiLeaks for archivists is a good

${ }^{11}$ Peter Carini, "Archivists as Educators: Integrating Primary Sources into the Curriculum," Journal of Archival Organization 7 (2009): 41-50.

12 Kathleen Roe, Teaching with Historical Records (Albany: New York State Archives, 1981).

13 Julia Hendry, "Primary Sources in K-12 Education: Opportunities for Archives," The American Archivist 70 (Spring/Summer 2007): 116.

${ }^{14}$ Lee Ann Potter, "Education Programs in the Presidential Libraries: A Report from the Field," Public Historian 28 (2006): 133-42. In one of the more important assessments of the use of archival sources in the classroom, Sharon Anne Cook writes, "An educational system which is invited to use archival resources intelligently gains in many ways as well. Take, for example, teachers of Canadian history. The 'new history,' mandated by virtually all Ministries of Education privileges higher-order thinking skills, document analysis, and an understanding of the historical process rather than its content. 'Studentcentered' education requires that learners in any given classroom will be provided with a range of resources of varying levels of difficulty and type so that student abilities and interests can be matched to promote learning. These two foundation principles of virtually all current history classrooms are further complicated by the decision in several provinces, including Ontario and British Columbia, to mainstream all abilities into common classrooms at the intermediate level (about grades seven to ten). Coincidentally, this is also the age when historical sensibility is first developing in students and when most provinces make one history/civics course mandatory in the curriculum." Sharon Anne Cook, "Connecting Archives and the Classroom," Archivaria 44 (Fall 1997): 107.

15 Hendry, "Primary Sources in K-12 Education," 129. 
example. ${ }^{16}$ WikiLeaks could be a good topic for teaching packets because it raises many questions about the nature of archival evidence; as Alasdair Roberts suggests: "Even in the age of the Internet, there is no such thing as the instantaneous and complete revelation of the truth. In its undigested form, information often has no transformative power at all." ${ }^{17}$ Whether we are committed to immersing students into archival sources to enhance critical thinking skills or to build a public better informed about the nature of archives, WikiLeaks makes a good case in point.

Some have expressed concern about such roles for archivists in K-12 education. Marcus Robyns wonders, despite a growing interest by archivists in outreach and education, just what concepts such as critical thinking skills have to do with archivists or their materials. ${ }^{18}$ Robyns nevertheless suggests using the "critical thinking process as a set of criteria or guidelines," focusing on such matters as the "verification of facts," the "reliability of the source," "recognizing logical inconsistencies or fallacies in a line of reasoning," and "distinguishing between warranted or unwarranted claims." Robyns believes that archivists should be involved in reflecting on learning outcomes because of the problems associated with the weakened teaching of historical research methods in the university. ${ }^{19}$

It is wrong, however, to read too much into the growing use of archival sources in classrooms. Patricia Cleary and David Neumann argue, "Teaching with primary sources raises pedagogical problems that few proponents of their use acknowledge: the inappropriate, superficial, or decontextualized reading of documents." ${ }^{20}$ While proponents believe that working with these materials teaches students to function as historians (or archivists), the manner in which the documents are presented to the students raises critical and troubling issues. Joan Brodsky Schur describes how teachers attempt to put students in the shoes of common people by immersing them in documents and taking them to museums, historic sites, and historic houses. The goal is to get students to see the past critically through eyewitness accounts, namely diaries, travel accounts,

${ }^{16}$ Elena S. Danielson, "Secret Sharers: In an Age of Leaks, Forgeries, and Internet Hoaxes, Archivists Must Guard Information While Keeping Hackers at Bay,” The American Scholar (Autumn 2011): 39-46.

17 Alasdair Roberts, “The WikiLeaks Illusion,” Wilson Quarterly 35 (Summer 2011): 21.

${ }_{18}$ Marcus C. Robyns, "The Archivist as Educator: Integrating Critical Thinking Skills into Historical Research Methods Instruction,” The American Archivist 64 (Fall/Winter 2001): 364. For an example of the discussion on working with primary sources as a means of developing critical thinking skills in students, see Mary J. Johnson, "Primary Sources and Web 2.0: Unlikely Match or Made for Each Other?," Library Media Connection 27 (February 2009): 26-30.

19 Robyns, "The Archivist as Educator," 376.

${ }^{20}$ Patricia Cleary and David Neumann, "The Challenges of Primary Sources, Collaboration, and the K-16 Elizabeth Murray Project," The History Teacher 43 (November 2009): 67. 


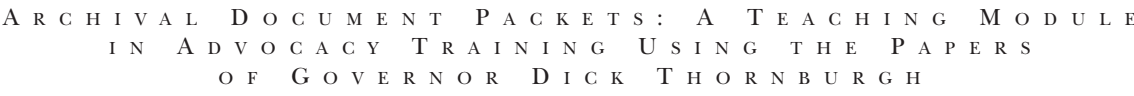

letters, newspapers, election speeches, and scrapbooks. ${ }^{21}$ Such statements connect to the National History Standards as well as predating them with case studies by both teachers and archivists of efforts to use archival sources in classroom projects. ${ }^{22}$

Archivists, and other professional staff at historical sites, museums, and cultural resources repositories, ought to see the possibilities for working with both K-12 and college and university teachers. Mary Babson Fuhrer reports on the preparation of an exhibition at the National Heritage Museum, which included workshops for elementary and high school teachers in using "primary sources to recover a lost world." ${ }^{23}$ The Slavery and Justice Committee at Brown University used primary sources for its investigative report on the university's participation in slavery and the international slave trade. These sources were central to the study, permitting students and others to understand a troubled institutional memory on historical, political, and legal grounds. One of the recommendations in the report was to create educational curriculum around primary sources. ${ }^{24}$ In New York, the work of three historians consulting on a local community exhibit with a historical society emphasizes the value of primary sources. They developed a social, historical, statistical database drawing from manuscript censuses of 1905 and 1925 that could guide future exhibitions and public outreach work, especially in the classroom. ${ }^{25}$ These kinds of educational projects that draw on documentary materials occur in every kind of archival and historical repository and site, and they present common challenges.

Problems occur because, generally, the educators focus on the use of primary sources as pedagogical issues, such as critical thinking skills, rather than on learning about the substance of archives or historical research methods. Information literacy is often the focus, which revolves around the analysis of primary sources and using them to understand various "people, events, themes, and concepts" ${ }^{26}$ in ways beyond simplistic Google searches. ${ }^{27}$ In light of

${ }^{21}$ Joan Brodsky Schur, Eyewitness to the Past: Strategies for Teaching American History in Grades 5-12 (Portland, Maine: Stenhouse Publishers, 2007).

22 See "National History Standards, Part I Standards in Historical Thinking," OAH Magazine of History 9 , no. 3 (1995): 7-12; Mary E. Anthrop, "History Day Advisor Tells How Students Got Started," OAH Magazine of History 1 (1986): 30-33; and Katherine T. Corbett, "From File Folder to the Classroom: Recent Primary Source Curriculum Projects,” The American Archivist 54 (1991): 296-300.

23 Mary Babson Fuhrer, "From Sources to Stories: Reconstructing Revolutionary Lexington in the Classroom," History Teacher 42 (August 2009): 498.

24 The website for this project is available at http://brown.edu/Research/Slavery_Justice/, accessed 15 October 2012.

25 Bill Gibbs, Lois Nettleship, Edward Orser, and Anne Webb, "Classroom, Research, and Public History: An Integrated Approach,” Public Historian 7 (1985): 66-67.

${ }^{26}$ From Best Practices Bulletin: Information Literacy; Setting Library of Congress Research Goals (Arlington, Va.: Adventure of the American Mind Northern Virginia Partnership, n.d.).

27 Thomas Steman and Susan Motin, "History Day: Another Outreach Opportunity for Academic Libraries," College and Research Libraries News 71 (January 2010): 28. 
declining employment opportunities, historians are retooling the education of the next generation toward teaching history in K-12 schools, recognizing that they have new opportunities such as developing "document-based questions" on advanced placement tests ${ }^{28}$ and in creative uses of the Web. ${ }^{29}$ Whether students actually learn something about the nature and value of archives may be only a coincidence, but the prospects of introducing students to archival careers seem good.

Archivists have tried to use the idea of critical thinking and other skills to get their archival materials into the mix, as a means of advocating for their use. Some seem to show promise. Here is but one example: "DESCRIBE is an instructional strategy used by teachers to guide students through reading and analyzing text-based primary sources." Aimed to "aid students in activating background knowledge" and "understanding key vocabulary and comprehending text," DESCRIBE is "based on seven research-based instructional principles" such as "actively involving students in the learning process" and "distinguishing important information from unimportant information." ${ }^{30}$ It is easy to see how archival materials can be used in advancing such principles.

Some academic archives offer instruction for undergraduates about the use of their holdings. ${ }^{31}$ John J. Grabowski describes an introductory United States history course at Case Western that draws on the collections of the nearby Western Reserve Historical Society: "Seeking to dispel the standard undergraduate misconceptions about history - that it is boring, distant, nonrelevant, just dates, etc.- - we had prompted our students to get outside the classroom, to observe life on the streets and neighborhoods around the university, and to use the archival and material culture collections of a major museum in an effort to understand a critical issue, unity or disunity in the

${ }_{28}$ American Historical Association et al., The Next Generation of History Teachers: A Challenge to Departments of History at American Colleges and Universities (2007).

${ }^{29}$ Kathleen M. Noonan, "Untangling the Web: The Use of the World Wide Web as a Pedagogical Tool in History Courses," The History Teacher 31 (February 1998): 217.

${ }^{30}$ Colleen Reardon and C. Ben Freville, "DESCRIBE: A Strategy for Making Text-Based Primary Sources More Accessible," Teaching with Primary Sources Quarterly (Fall 2009): 3. The name DESCRIBE comes from the following steps:

Describe the document.

Explain the concept.

State the unit.

Comb through the document for unique features and new vocabulary.

Read and as you read ask yourself, "What is this about?"

Indicate your response in the appropriate box.

Bring it all together.

${ }^{31}$ See Anna Elise Allison, "Connecting Undergraduates with Primary Sources: A Study of Undergraduate Instruction in Archives, Manuscripts, and Special Collections" (master's paper, University of North Carolina at Chapel Hill, School of Information and Library Science, April 2005). 


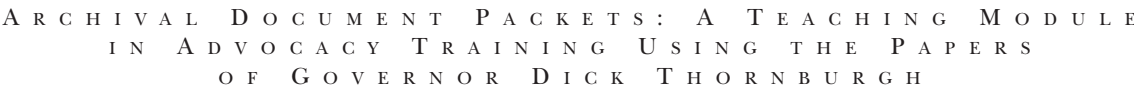

United States." ${ }^{22}$ Here we see advocacy as a reason for teaching students about archival sources. Xiaomu Zhou studied the process of teaching undergraduates about archival sources and their evidence. She describes the orientation given to undergraduates at the University of Michigan by the Bentley Historical Library, analyzing one class in American history and concluding, "Archival orientation is a complicated activity. In a very limited time, students need to acquire new knowledge and skills, such as general archives concepts, specific knowledge of the archives' holdings, organization of archival records, accessing rules of archival materials, the concept of finding aids and archival searching skills, and so on." ${ }^{33}$ Beth Ann Koelsch, in a survey about the use of ephemera from academic special collections, finds that "undergraduate instruction using archives and archives materials is not very common. Many students are not aware of the special collections libraries and archives within their universities." ${ }^{34}$ Deirdre Stam affirms the value of such activity in this simple but profound statement: "Teaching from the material is the most obvious way to bring a steady and manageable stream of visitors into special collections." ${ }^{35}$

In general, little research has been done about how university and other archivists engage in such teaching activities. ${ }^{36}$ However, the opportunities for both research and advocating a stronger meaning for archives in society are abundant. Anne Gilliland notes the underresearched nature of this area of archival work. ${ }^{37}$ According to Gilliland, here is the opportunity:

Addressing the educational needs of K-12 communities represents an unparalleled opportunity for archivists to a) expand the relevance of archival repositories within society; b) begin to grow a "records literate" as well as "information literate" audience that is aware of the importance, relevance, and complexities of records as bureaucratic, social, political, and cultural evidence; c) promote the role of archivists as active participants in the

32 John J. Grabowski, "Going Public with Introductory American History,” The Journal of American History 88 (March 2002): 1451.

33 Xiaomu Zhou, "Student Archival Research Activity: An Exploratory Study," The American Archivist 71 (Fall/Winter 2008): 493.

${ }^{34}$ Beth Ann Koelsch, "Research and Instructional Uses of Ephemera and Realia in Academic Library Archival Collections" (master's thesis, University of North Carolina at Chapel Hill, April 2007), 26.

35 Deirdre C. Stam, "Bridge that Gap! Education and Special Collections," RBM: A Journal of Rare Books, Manuscripts, and Cultural Heritage 7 (Spring 2006): 19.

36 Wendy M. Duff and Joan M. Cherry, "Archival Orientation for Undergraduate Students: An Exploratory Study of Impact," The American Archivist 71 (Fall/Winter 2008): 499-529. For case studies, see Dorothy T. Frye, "Linking Institutional Missions to University and College Archives Programs: The Land-Grant Model," The American Archivist 56 (Winter 1993): 36-52. She argues, "One of the most direct ways an archives can utilize the land-grant mission is to actually participate in the extension component of that mission by offering workshops, producing exhibits, and working closely with the faculty to support primary-source research on the undergraduate as well as graduate level," 50 .

37 Anne J. Gilliland-Swetland, “An Exploration of K-12 User Needs for Digital Primary Source Materials," The American Archivist 61 (Spring 1998): 137. 
communication of cultural heritage; d) take advantage of the technological and financial resources that are being allocated nationally for the application of information technology in the classroom and for educational reform; and even e) promote archival education as a possible college choice. ${ }^{38}$

Gilliland considers educational theory, state standards for teaching history, and trends in the archival community such as user studies, and lays out research needs in light of digitization and K-12 learning objectives.

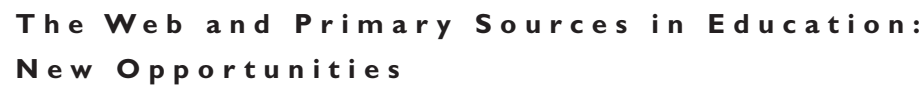

Concerns with digital archives have become more important since the growing number of archival sources on the Web increases the possibility for new teaching ventures. John Lee notes that the Web increases document accessibility, allowing for "learner-centered experiences" and a "more personal understanding of history. Through the World Wide Web, learners have a level of direct access to the raw materials of history that educators could never have imagined." 39 Making such distinctions provides for a teachable moment. As a result, some teachers are gravitating to websites with primary source materials in an effort to design their own teaching packets and to avoid the issues of bias and other political constraints that they encounter at other websites. The Organization of American Historians suggests that "Although teachers can use these heavily biased sites to help students understand all points of view, documents are available that allow students to make their own decisions without appearing to endorse one view or the other." ${ }^{40}$ Lee Ann Potter describes the presidential libraries' efforts "to develop broader and more sophisticated programs on-site and at a distance. Many of these programs demonstrate an awareness of educational research into multiple intelligences, and embrace educational methods that include cooperative learning, authentic assessments, and projectand performance-based learning. In addition, the programs draw from both the archival and the museum components of the institutions and seek to address the needs of both educators and students some of whom are quite young." 41 Because a variety of political issues and questions plagues these institutions, especially regarding access to their records and the interpretations presented

\footnotetext{
${ }^{38}$ Gilliland-Swetland, "An Exploration of K-12 User Needs," 137.

${ }^{39}$ John K. Lee, "Digital History in the History/Social Studies Classroom," The History Teacher 35 (August 2002): 504.

40 Organization of American Historians, "Teaching with the Web: Using the Internet to Teach American Conservatism," Magazine of History 17 (January 2003): 58.

41 Potter, "Education Programs in the Presidential Libraries," 134.
} 


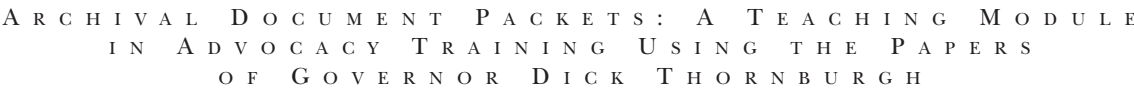

by their exhibitions, one might question just what perspective their educational programs present. ${ }^{42}$

What have archivists done to encourage the use of their materials by $\mathrm{K}-12$ and college students, especially given the ready availability of the World Wide Web for their dissemination? The National Archives offers teachers a range of services via its website, such as prepared lesson plans that incorporate archival resources, topic-specific pathfinders, and DocsTeach, an online tool to help teachers construct learning activities and build minicollections of primary sources ${ }^{43}$ State government archives have established sites providing information about state history for students doing local and state history reports. ${ }^{44}$ Archival repositories specializing in different documentary forms or topical areas provide websites for use by both K-12 teachers and students, ${ }^{45}$ although many focus on providing advice to teachers or in producing textbooks for use in the schools without necessarily emphasizing the use of historical documents. ${ }^{46}$ A number of archives have published document teaching packets, both online and in print form. ${ }^{47}$ The Maryland Historical Society sells document packets on a number of themes to "make history come alive" and to "help... students make a personal connection with the past." 48 Many archives and historical societies offer kits that schools can borrow. The Montana Historical Society offers "Hands-On History Footlockers," with

. . reproduction artifacts; photographs; cassette tapes, video tapes, PowerPoints and/or DVDS; reproduction clothing; and replicated tools related to the specific footlocker topic. Footlocker User Guides can be found

42 See Richard J. Cox, "America's Pyramids: Presidents and Their Libraries," Government Information Quarterly 19 (2002): 45-75.

43 See "Archives Library Information Center," National Archives, http:/ /www.archives.gov/research/ alic/reference/black-history.html; "Teachers," National Archives, http://www.archives.gov/ education/lessons/; and "DocsTeach," National Archives Experience, http://docsteach.org/, all accessed 25 October 2011.

${ }^{44}$ See, for example, "K-12 Education," Utah.gov, http://www.utah.gov/education/k12.html; "Lesson Plans, Classroom Activities," Alabama Department of Archives and History, http://www.archives. alabama.gov/teacher/index.html, both accessed 25 October 2011.

45 Such as the "For K-12," George Eastman House International Museum of Photography and Film, http://www.eastmanhouse.org/inc/education/k-12.php, accessed 25 October 2011.

${ }^{46}$ Examples include "Curriculum," Georgia Historical Society, http://www.georgiahistory.com/ containers/38, and the Kansas State Historical Society, http://www.kshs.org/teachers/index.htm, accessed 25 October 2011.

47 The Illinois State Archives has produced teaching packets on topics such as the depression and canal building; see the packets at http://www.cyberdriveillinois.com/departments/archives/teaching packages/home.html. The Arizona Historical Society Education and Outreach Division offers a variety of document teaching packets and other free online links to history materials at http://www .arizonahistoricalsociety.org/education/, accessed 25 October 2011.

${ }^{48}$ From "Primary Source Kits," Maryland Historical Society, http:/ /www.mdhs.org/education/Kits.html, accessed 12 July 2010. That the society sells these in print form rather than offering them online probably attests to the private nature of the historical agency. 
online, in Adobe Acrobat format, to help teachers prepare for utilizing this resource in the classroom. These Guides contain: historical narratives; a bibliography; compliance with Montana Standards for Social Studies and Indian Education for All Essential Understandings where applicable; and lessons. In the User Guide you will also find many tools to assist you in teaching with objects and primary sources. ${ }^{49}$

Some historical societies are preparing teaching aids for use in guiding students around their exhibitions, with a focus on both artifacts and documents. ${ }^{50}$ Others provide specific advice on how to read a historical document and to do historical research. ${ }^{51}$ The State Historical Society of North Dakota provides online document sets to accompany a state history textbook. ${ }^{52}$ The various teaching packets contain a variety of arguments for why they've been created. The Illinois State Archives' packet on the Great Depression states that students "often are not excited by traditional instruction in American history," particularly because "textbook treatments consist of dry narratives of impersonal facts which have little relevance to students' immediate lives." 53 This institution's packet suggests a template for document packets, including Introduction, Objectives, Use of Documents, Historical Background, and Selected Bibliography. The documents follow, each with a digital image, explanation, and points to consider. Some historical agencies offer guides for teachers working with students in the use of historical documents. The Ohio Historical Society provides two thousand pages of historical documents and a guide for teachers that covers objectives, definitions, and questions to guide students in their examination of the sources. ${ }^{54}$

Fortunately, some experienced teachers offer their insights about basic design and pedagogical principles. Joan W. Musbach provides "common-sense rules," such as keeping the materials "age appropriate," making sure they are

${ }^{49}$ From "Footlockers," Mt.gov, http://mhs.mt.gov/education/footlocker/default.asp, accessed 10 July 2010. For other examples, see "Traveling Trunk Program," Oregon Historical Society, http:/ /www.ohs .org/education/traveling-trunk-program.cfm; "Hands-On History," Virginia Historical Society, http://www.vahistorical.org/education/education_handson.htm; and "History Boxes," Washington State Historical Society, http:/ /www.washingtonhistory.org/education/historyboxes.aspx, all accessed 10 July 2010.

${ }^{50}$ Such as the Kentucky Historical Society, http:/ / history.ky.gov/sub.php?pageid=91\&sectionid=11; and "Education," New-York Historical Society, https:/ / www.nyhistory.org/web/default.php?section=educ ation\&page=digital_resources, both accessed 10 July 2010.

${ }^{51}$ Such as "How to Use Primary Sources," New Jersey Historical Society, http://www.jerseyhistory.org/ howtofind.html, accessed 25 October 2011.

${ }^{52}$ Available at "Educators," State Historical Society of North Dakota, http://history.nd.gov/educators .html, accessed 10 July 2010.

53 This packet can be found at http://www.cyberdriveillinois.com/departments/archives/teaching packages/hard_times/home.html, accessed 9 August 2012.

${ }^{54}$ Available at http://www.ohiohistory.org/education, accessed 9 August 2012. 
A R C H I V A L D O C U M E N T P A C K E T S : A $\mathrm{T}$ E A C H I N G

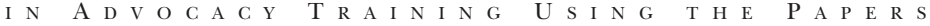

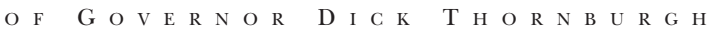

"readable," and supplying "adequate background." Musbach, who teaches eighth-grade American history, concludes her essay this way:

Because I believe in the value of using primary sources in the teaching of history, I am concerned that the results be positive. Inappropriate selections, or poorly crafted lessons can lead to a bad experience for a teacher who may then dismiss primary sources as a bad idea. Instead of being energized, students can be turned off to history and the work of historians. Using primary sources requires judgment and skill..$^{55}$

Others express similar thoughts. ${ }^{56}$ Bill Tally and Lauren B. Goldenberg add that "students need to be both cognitively active and emotionally engaged when working with" documents, by carefully evaluating the records, making "personal connections," and learning to "use evidence to support their speculations."

These testimonies about the potential of teaching packets to orient students to the nature of archival sources also suggest another potential for teaching about archival advocacy. If we fail to take advantage of these opportunities, we lessen the chances of informing future generations about the value of archival sources, a message we need to emphasize in teaching future archivists.

\section{Teaching Packets and Building Advocacy Skills in Archivists}

A review of the efforts to engage students, at all levels, with archival sources moves along familiar territory-learning how to do research, supplementing lifeless textbooks, expanding knowledge of the world and the local community, creating jobs for underemployed historians and archivists, supporting character education, spurring on higher-order thinking skills, meeting national history standards, building up use statistics of archival materials, and making the public more aware of archivists and their mission. From the perspective of designing a graduate curriculum to prepare students for archival careers, the design and use of archival teaching packets open up a large window into how archivists interact with people to help them better understand the nature and importance of archives.

For a number of years, the University of Pittsburgh graduate archives program has offered a course on archival access, advocacy, and ethics. The emphasis of the course changes every year to focus on one of these critical archival functions. In the spring 2011 version of this course, we focused on

55 Joan W. Musbach, "Using Primary Sources in the Secondary Classroom," OAH Magazine of History 15 (Summer 2001), available at http://www.oah.org/pubs/magazine/greatdepression/ musbach.html.

${ }^{56}$ Gibbs et al., "Classroom, Research, and Public History,” 69-70.

57 Bill Tally and Lauren B. Goldenberg, "Fostering Historical Thinking with Digitized Primary Sources," Journal of Research on Technology in Education 38 (2005): 1. 
advocacy. Archival advocacy, often called public programming or outreach (or, at least, encompassing these activities), which archivists have adopted to build public support for their programs, is particularly important to archivists, manuscripts curators, and other records professionals because of the many competing information sources and because of technological and other changes to the way archives and historical records are made accessible. While reference and access have been associated with the modern archival profession from the beginning, archival advocacy has developed over the last generation. Archival access and advocacy connect the work of archivists and other records professionals to a variety of publics interested in the welfare of the documentary heritage.

This course focused on archival teaching packets as a form of archival advocacy. Students learned about the practical issues involved in building teaching packets that draw attention to archival holdings and inform the public about the nature and value of archival sources, and the relationship of archival programs to educational venues from middle school to the university. The archival teaching packet project was created with a small development grant from the Dick Thornburgh Forum for Law and Public Policy. Students participated in group projects to create document teaching packets using the Governor Dick Thornburgh Papers at the University of Pittsburgh. The project served as a testbed for developing teaching packets for use by college (and other) students that highlight the value of archival records in understanding law, public policy, and other high-profile matters reflected in these records.

Dick Thornburgh was the governor of Pennsylvania from 1979 to 1987 and U.S. attorney general from 1988 to 1991 . He is primarily known for his strong stand on ethics in government, his handling of the Three Mile Island nuclear reactor accident in 1979, and his advocacy for the Americans with Disabilities Act enacted in $1990 .{ }^{58}$ His papers, over a thousand boxes, are located at the Archives Service Center at the University of Pittsburgh. ${ }^{59}$ The Thornburgh Papers lent themselves to group projects. Small groups of students (five to eight in each group) worked on developing teaching packets related to particular topics featured in the Thornburgh Papers. The students were to identify and select an audience and determine a presentation format. A fundamental question they needed to answer related to the depth and breadth of coverage in the teaching packet. What should be included? Excluded? Such decisions can potentially lead to charges of bias, and so the students had to provide a rationale and properly contextualize the events presented in their teaching packets.

\footnotetext{
${ }^{58}$ Governor Thornburgh has written an informative memoir, Where the Evidence Leads: An Autobiography (Pittsburgh: University of Pittsburgh, 2003), recently re-issued in 2010 as a paperback with a new chapter.

${ }^{59}$ An extensive inventory can be found at University of Pittsburgh, "The Dick Thornburgh Papers," http://www.library.pitt.edu/thornburgh/, available as this essay went to press.
} 


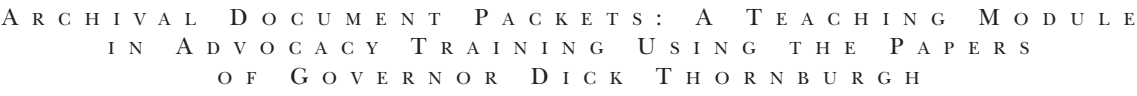

Some students worked in the archives to identify the documents to be used, and others in each group worked on background research on the topic, reading about the preparation of teaching packets, investigating Pennsylvania history as it is taught in high schools, and considering the best means by which to publish and disseminate the teaching packets. Each group prepared a background paper on the development of its packet as well as on the packet itself. The students' teaching packets were given to the Thornburgh Forum and the University of Pittsburgh Archives Service Center for whatever use they wished to make of them. From the perspective of the instructors, the primary objective was giving the students an opportunity to learn about such educational and advocacy work.

The aim of these projects was to contribute to students' understanding of various ways they can use teaching packets to advocate for archival programs and the increased use of archival sources. A secondary aim was to develop a model or framework for what such teaching packets should look like, especially in an online format. The goal was not to produce final publishable teaching packets but to have students learn about this form of archival public programming. As an added bonus, this project presented the opportunity for the archives students to work in archival materials, many for the first time. ${ }^{60}$

The Thornburgh Papers is a rich collection, documenting all aspects of the governor's life and career, ranging from a childhood diary to corruption and gambling cases prosecuted when Thornburgh was U.S. attorney general. There are detailed files on his various election campaigns, records concerning crises he handled (most notably the Three Mile Island nuclear reactor crisis), and foreign trips. The range of archival materials in the Thornburgh Papers is considerable, and they can support projects focusing on particular kinds of documentary resources, such as correspondence, memoranda, court opinions, notes of meetings, newspaper and other articles, scrapbooks, schedules, speeches, unpublished essays and position papers, press releases, telephone logs, audio and video recordings, and radio and television transcripts. While the collection provides a number of possibilities for studying the nature of records and recordkeeping systems, it also presents the opportunity to consider the archiving of gubernatorial and personal papers and the issue of access to government records.

${ }^{60}$ We have since changed admission requirements. Archives, Preservation, and Records Management students must have a year's experience in archives and demonstrate other knowledge of archives to be admitted. 


\section{The Students and Their Projects}

After several introductory weeks orienting students to the basic issues and activities of archival advocacy, access, and ethics, we began to focus on the nature of archival teaching packets and various case studies related to these archival functions. The first part of this course is always a bit difficult for students, given that these particular functions can generate considerable unease since most students have not really thought through the implications of archival advocacy and ethics. ${ }^{61}$ When they matriculate into the program, many new students believe that archives are both well known and well supported-which is, of course, not the case. Archival access, focusing on the reference process and archival user studies, is a reasonably benign topic, but the other functions stimulate testy discussions that are important for students to have before they enter into archival positions. Fortunately, we have some nicely balanced texts on topics such as archival ethics that orient students to complex issues ${ }^{62}$ as well as some explorations of the uncomfortable implications of such issues. ${ }^{63}$ The purpose of this course is to immerse students in these difficult issues in the safe and neutral environment of the classroom.

After the introductory sessions grounded students in the functions of archival access, advocacy, and ethics, we oriented them to how archivists and teachers think about archival teaching packets. Students were assigned a number of the essays about document teaching packets cited above. Leanne Bowler, an assistant professor in Children's and Youth Services at our school, described for the students a research project she had been involved with in Canada to build Web portals to help connect elementary students with Webbased resources in Canadian history, many of which are found in archives. She

${ }^{61}$ This course has evolved through the years, but it has been documented in the writings of Richard J. Cox, including "Advocacy in the Graduate Archives Curriculum: A North American Perspective," Janus 1 (1997): 30-41 and "Unpleasant Things: Teaching Advocacy in Archival Education Programs," InterActions: UCLA Journal of Education and Information Studies 5 (2009), eScholarship University of California, http://repositories.cdlib.org/gseis/interactions/vol5/iss1/art8, accessed 25 October 2011.

${ }^{62}$ See, for example, Elena S. Danielson, The Ethical Archivist (Chicago: Society of American Archivists, 2010) and Karen Benedict, Ethics and the Archival Profession: Introduction and Case Studies (Chicago: Society of American Archivists, 2003).

${ }^{63}$ See Richard J. Cox, Ethics, Accountability, and Record Keeping in a Dangerous World (London: Facet Publishing, 2006) and Richard J. Cox and David A. Wallace, eds., Archives and the Public Good: Accountability and Records in Modern Society (Westport, Conn.: Quorum Books, 2002). 


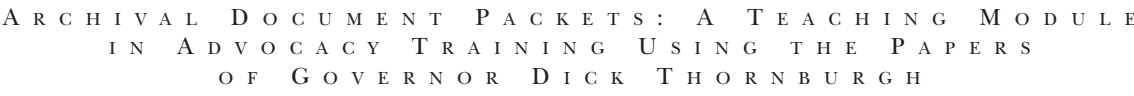

served as a resource to students in the class wanting to discuss the nature of such efforts. ${ }^{64}$

Professor Bowler highlighted some of the problems that children in elementary school might have using archival materials. For example, documents handwritten in cursive can be difficult for children to read. Also, children have trouble understanding time because essentially, for nine-year-olds, everything is "old." The question of interpretation is problematic in all archives, but because children, and even teens, may have trouble synthesizing meaning from collections of primary sources on their own, teaching packets may need to be contextualized more for their young users. But how much interpretation is appropriate?

A good portion of the Thornburgh Papers consists of audiovisual materials. For instance, online users have access to fifty-five digitized videos from a collection with over five hundred moving image elements that range from commercials to news footage to public programming. Janet Ceja Alcalá, an archives doctoral student focusing on moving image archives, presented several lectures to the class on the history of video, the basics of analog video preservation, reading visual texts, and the nature of knowledge offered by moving images, with a focus on how video formats can be used to promote creativity and collaboration in archives. These lectures, which also included in-class activities, were intended to help students incorporate audiovisual materials into their advocacy efforts to engage their audiences.

As it turns out, relatively little research exists about Thornburgh and his public service, with the possible exception of studies of the Three Mile Island crisis. ${ }^{65}$ The lack of research materials was somewhat resolved by a visit by Dick Thornburgh, his wife Ginny, and Thornburgh archivist, Nancy Watson. Governor Thornburgh provided an inspirational lecture about not only the nature of his personal and official papers, but also why he made the records readily accessible to all researchers without any restrictions (a rare decision by a living, high-ranking government official).

At this point, we were two-thirds of the way through the course. The remainder of the course examined archival access, advocacy, and ethics case studies. These case studies follow issues and concerns that are pre-eminent challenges within the archival profession and that connect to aspects of the

${ }^{64}$ For background, see L. Bowler, V. Nesset, A. Large, and J. Beheshti, "Using the Web for Canadian History Projects: What Will Children Find?," Canadian Journal of Library and Information Science 28 (2004): 3-24; A. Large, L. Bowler, J. Beheshti, and V. Nesset, "Bonded Design, Intergenerational Teams and the Zone of Proximal Development: Working with Children as Designers," McGill Journal of Education, 42 (2007): 61-82; and A. Large, J. Beheshti, V. Nesset, and L. Bowler, "Designing Web Portals in Intergenerational Teams: Two Prototype Portals for Elementary School Students," Journal of the American Society for Information Science and Technology 55 (2004): 1140-54.

65 See, for example, J. Samuel Walker, Three Mile Island: A Nuclear Crisis in Historical Perspective (Berkeley: University of California Press, 2004). 
Thornburgh Papers that could be featured in teaching packet projects. These topics included access to government records, personal privacy, archival and information security, and other such issues. We considered cases such as the matter of open access to the Archives and Archivists Listserv Archives, the NARA reclassification scandal and other issues pertaining to government secrecy, various incidents of archival theft (from both inside and outside), controversies about the role of archives in wartime and the memory of wars, ethical aspects of corporate archives and records management, and the equipping of citizen archivists as a form of archival advocacy. The aim was not to provide a comprehensive review of all these archival functions, but to examine in depth a few particularly revealing cases to give students a sense of how these issues played out in various kinds of archival repositories and in the profession.

We finished the course with group presentations about their document teaching packets. Each group picked a different focus and aimed at the audience of its choice. One group chose the topic "lessons on leadership," which grappled with cases of questionable or controversial leadership on Thornburgh's part. Another group focused on the impact of the media on Thornburgh's 1991 unsuccessful campaign for the U. S. Senate. A third explored Dick and Ginny Thornburgh's advocacy efforts on behalf of the passage and implementation of the Americans with Disabilities Act. One group examined the idea of accountability in government in the Thornburgh era, building on Thornburgh's own interest in ethics in government and one of the themes of this course. The final group, comprising distance students participating online, focused on Thornburgh and the 1967-1968 Pennsylvania Constitutional Convention, an early seminal event in Thornburgh's career. The class presentations also assessed the students' abilities at organizing and presenting a group project and the efforts availed an array of success with this.

The course syllabus specified the project requirements and a grading rubric, and, using the rubric, each group was given feedback by the instructors about its presentation. The assignment required each packet to contain ten to twenty documents and the collaborative writing of a report on the process of assembling the packet. For the final presentation, each group presented a brief report about what it produced, challenges faced, problems overcome, and what it learned about using archival documents to advocate on behalf of archives and to generate use of archival holdings. The groups submitted their document packets, with supporting materials, electronically, posting them to the educational software system Blackboard so that the students could review and discuss each group's work in the final class sessions.

Students were allowed to self-select into their groups, with the exception of those taking the course via distance education. These seven were required to work as one group, and their assignment was to develop a teaching packet 


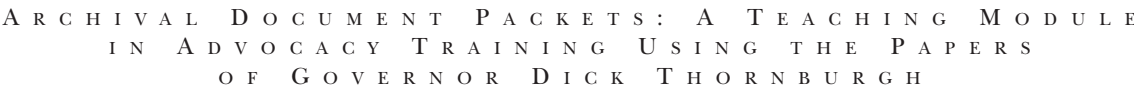

utilizing materials available on the Thornburgh Papers website and to consider the particular issues and challenges involved in such an effort. We graded students individually by their class participation and discussion (30 percent of the grade) and the group project (70 percent). The grade for the group project was based on the final group product, not individual performance within the group to make the project more like a real work experience and to encourage students to resolve the problems they faced as they might in their future employment. (While this generated some tension, it seems to have worked, and the groups resolved and improved the performance of students not pulling their weight.) We graded the group projects (including both the document teaching packet and the accompanying paper about its preparation) based on 1) clarity of writing, organization, and oral presentation (20 points);2) originality of topic (10 points); 3) thoroughness of research (20 points); and 4) effective use and mastery of pertinent professional and scholarly literature (20 points).

As their audiences, the groups selected high school seniors in a civics, American history, or American government class; college-age students; the general public who might be interested in the topics of the teaching packets; and Thornburgh himself. Except for two groups that did a fine job in reading into educational standards, enhancing their knowledge of their intended audiences, the quest for an audience proved to be one of the key challenges the groups faced.

Each group divided up responsibilities for searching within the Thornburgh Papers; meeting with the Thornburgh archivist, Nancy Watson; and working with other archivists, such as Miriam Mieslik, who is responsible for the photographic and audiovisual archives in the University of Pittsburgh Archives Service Center. A portion of each class session was devoted to group meetings and consultation with the instructors.

Both students and instructors learned through the work in these group projects. Many of the students, despite being in a graduate archives education program and preparing for archival careers, had limited experience in working with archival materials either as researchers or archivists. Some felt frustrated by the nature of the finding aids, the duplication of materials in the Thornburgh Papers, and the slowness of the process of working through the collection. None of these frustrations related to the nature of the Thornburgh Papers or how they are organized or described - theywere just reactions by individuals inexperienced in such work. Some students wondered about how the documents in the Thornburgh Papers were selected to be preserved or digitized, a topic that most students were wrestling with in another course on archival appraisal they were taking in the same term. Even as the students wondered about the processes of constructing archival finding aids and appraising the materials, they needed 
coaxing to relate these professional functions to their own tasks in selecting documents to be included in their teaching packets (especially since not all groups were explicit about how the documents were selected). In fact, student critiques indicated that they began to see how someone using archival materials with modest experience in archival finding aids might feel, and that knowledge cannot be anything but positive as they begin their archival careers (especially because most entry-level positions are in the reference room and preparing finding aids).

Students also learned about educational standards, such as the Pennsylvania Education Standards and the American Library Association Standards for the Twenty-first Century Learner. Examining such standards also stimulated students to think about how to identify and define an audience, an immensely valuable aspect of learning about being a good advocate. One of the groups examined standard high school textbooks and met with a high school curriculum specialist to help plan and design its teaching packet; members of this group were uneasy about their own lack of experience as teachers, but that is exactly the point in such an exercise: archivists generally will not have had most of the experiences of their actual or desired researchers, and learning how to bridge such gaps is critical to being effective advocates for their archives.

Working on these teaching packets also provided an opportunity for students to think about issues like design and presentation, as well as how able their intended audiences might be to understand and use the sources in the teaching packet. Even though the majority of these students are digital natives, it seemed difficult for some to apply whatever practical experience they had into fully coherent or complete assemblages for their packets. Again, from an educational perspective this was not a negative, as it raised issues for discussion that ought to assist students as they transform into working archivists. Sooner or later, novice archivists mature and begin to understand that the public assumes much more than it knows about archives. The online student group exceeded our expectations in producing a clear and engaging video about what it did to produce its teaching packet.

Many of the students did not use their work with the teaching packets to understand the nature of documents and communicate what they know. Some of the groups used the extensive newspaper clippings in the Thornburgh Papers to convey information about Thornburgh's life and career, but they did not take into account that today's high school and college students might not have much of an idea about what the old-fashioned print newspaper represented. They are either accustomed to reading newspapers online or not reading newspapers at all (instead reading blogs and other news surrogates). Here was an opportunity to reflect on the nature of documents, a topic certainly relevant to advocating on behalf of or educating about archives and their materials, and there is an 


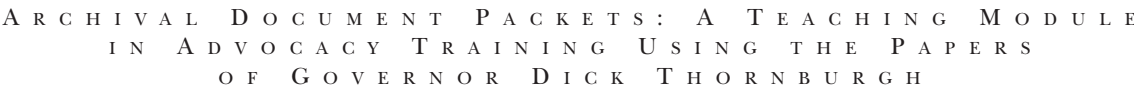

extensive scholarly and professional literature about documentary sources that can be used to support this. For example, examining such literature could have led to some intriguing speculation about how current events might be documented in the future, especially given the tremendous shifts (or decline) in the nature of the news media and the shift to news blogging and other techniques. One of the groups did provide some contextual information about the nature of media and documentary forms, but it was not done consistently (probably the result of both the nature of the group project and its time constraints). This group tied into the useful notion of media literacy and presented its information and learning objectives very clearly.

There were other challenges. Each of the groups also struggled with determining how much contextual information to include in its teaching packets. Although we asked the groups to include citations to seminal literature in both their teaching packets and background papers, we found this to be fairly thin across the five projects. Having students work in groups is an interesting way to observe and comment on their communication and interpersonal skills. Individuals seeking references for these students when they apply for jobs almost always ask about their ability to communicate and to collaborate. For some reason that was not completely clear, one group opted not to have a designated group leader, and it experienced a number of communication problems that negatively influenced the final production of its teaching packet. Still, this group's final report provided very honest self-assessment about these problems, which indicates that learning about such group work had occurred. Our sense is that the individuals in this group will be better prepared for the kinds of practical work they will have to do in their first archives positions.

\section{Conclusion}

The problems that students had providing context, combined with the difficulties some encountered aligning their projects with state educational standards or broad media literacy competencies, suggest that collaboration with teachers in the field would be helpful. One suggestion we offer for future iterations of this project is to bring a practicing teacher into the project, if not the actual archives class, and connect the teaching packets with a real-world learning experience in an undergraduate or $\mathrm{K}-12$ class.

The Thornburgh Papers project affirms that we can immerse archivists-intraining both in contemplating how to be advocates and in working with original source materials in ways that they have not before. They begin to learn how to communicate about archives and their value to individuals who have little idea about what goes on within archival repositories. The archival students themselves 
also begin to test their own assumptions and knowledge about archives, which will assist them in becoming better advocates.

Another way to consider this course and the teaching packets project is to understand this as an effort to relate praxis with theory. Despite considerable past efforts by archivists to work with educators to use archival materials in the classroom, and a fairly extensive literature considering these efforts, little has been done to determine the impact of such efforts on the archival profession or to build a stronger public understanding of archivists and archives. We hope that the students in our course, as they embark on their archival careers, will possess a greater sensitivity to such advocacy issues. The existing literature is old, scattered, and marked by gaps in conclusions. Students in our course read this literature, debated it, and, hopefully, will be prepared to make new and better contributions in the future. What they learned about archival advocacy will emerge as they gain experience in the field and have opportunities to practice what they learned. 